\title{
7 \\ Cross-cultural knowledge exchange in the age of the Enlightenment ${ }^{1}$
}

\author{
John Gascoigne
}

\section{Introduction}

One of the most characteristic features of European exploration of the Pacific was the extent to which it was linked with the Enlightenment-linked goals of promoting the acquisition of knowledge. This was often closely associated with the quest for imperial advantage or the search for wealth since knowledge brought with it the possibility of finding new sources of wealth. As the extent of trade around the world increased so, too, were habits of mind stimulated which formed a natural parallel with those required to accumulate the systematic bodies of knowledge on which science was based. The keeping of ledgers, the insistence on accuracy and the building up of networks which spanned more and more of the globe created a culture which was congruent with the values of science. ${ }^{2}$ The habits of mind promoted by the accumulation of wealth also

1 This chapter has drawn upon material from Gascoigne 2014 with the permission of the publisher, Cambridge University Press.

2 Cook 2007: 57, 58, 225, 410 . 
helped to shape the mentality of science and the preservation of knowledge more generally. Like science, successful commerce depends on records, on first-hand information and a critical and even sceptical attitude in the use of the available data. Establishing reliable inventories of information, which transformed the fleeting and contingent into manipulable data sets, was basic to both commerce and science. Increasingly, too, with the development of more sophisticated systems of accounting European capitalism promoted a quantifying spirit that became a way of viewing and understanding the world more generally. ${ }^{3}$

Knowledge, however, could also be an end in itself: the product of curiosity, a need to make sense of the world or to give greater dignity to intrusion on other lands and peoples. More subtly, too, it could be a way of reshaping a view of the world that reflected the outlook of a dominant culture. For empires are in part imagined constructions that give privileged status to the way in which the imperial power sees the world and to the knowledge systems that are built on such assumptions. ${ }^{4}$ Thus, as European science incorporated more of the world into its systems of classification and analysis, it took on a universalising aspect as local forms of knowledge from around the globe were translated into terms familiar to Europeans and amenable to European exploitation. The increasing dominance of the scientific world view from the late eighteenth century was, indeed, to be one of the most notable instances of the growing convergence of humankind.

Human divergence was, however, reflected in the multiplicity of forms of knowledge around the globe. Understandings of the way in which the world worked were linked to local needs and conditions giving rise to a great variety of knowledge systems. Knowledge was, for example, basic to Aboriginal society, which placed much less emphasis on possessions than Europeans. Survival was linked to knowledge of the local sources of water and food, along with the ritual forms that helped to sustain these. ${ }^{5}$ The need to identify and pass on knowledge about what types of plants and animals could sustain human life prompted the growth of systems of classification with particularly important types of animals being subdivided into forms which went beyond the boundaries of Western definitions of a particular species. Globalisation expanded the number and diversity of such 'contact zones' (as Mary Louise Pratt terms them), areas in which different cultures came into contact and, for all their differences, could share their forms of knowledge with each other. ${ }^{6}$

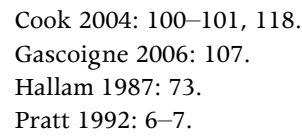




\section{Natural history}

Across the globe many such interactions between indigenous and Western systems of knowledge took place - though the effect tended to be to subsume the local in more generalised systems of knowledge. Natural history provided a way of drawing together such a vast range of information from around the world into forms familiar to Western culture. ${ }^{7}$ Natural history, then, extended beyond European charting of the world's surface to mapping the nature and extent of its flora, fauna, minerals and human population. The drawing together of diverse local knowledges into the generalising categories of natural history happened both at the global level and within Europe itself as folk knowledge was absorbed into learned discourse. ${ }^{8}$ This could mean that objects lost some of their cultural resonance as they were lifted out of the traditional frameworks of meaning with which they had been associated by particular localities or peoples. ${ }^{9}$ Loss of cultural specificity was countered by Western universalising which drew such diverse materials from around the world into forms of knowledge that were meant to be applicable for all peoples and places.

Natural history came to assume a growing importance and centrality in Western travellers' accounts, rising to particular prominence in the late eighteenth century when the Pacific came under close European scrutiny. As such systems waxed in authority, European openness to other systems of knowledge tended to wane. Such scientific self-confidence tended to parallel the rise of greater European imperial control over the globe, which brought with it less of an inclination to treat other cultures as having their own value as potential sources of new knowledge.

Generally speaking, Europe was more inclined to value knowledge from other parts of the globe in the earlier stages of the rise of science to the dominant system of intellectual authority that it became over the course of the eighteenth century. Following its foundation in 1660, the early Royal Society was very active in promoting the accumulation of knowledge from around the globe from whatever source. This was also true on the European Continent. In his address to Frederick II of Prussia of 1752, which set out the benefits of greater exploration of the globe in general and the South Seas in particular, the French scientist Pierre-Louis Maupertuis paid tribute to the advantages to be gained from studying other cultures' forms of knowledge, displaying particular admiration for Japanese medicine. ${ }^{10}$ Though Linnaeus's system of classification did much

\footnotetext{
Pratt 1992: 38; Smith and Findlen 2002: 18.

Drayton 2001: 237.

Raj 2004: 253; Chaplin 2001: 197-198.

0 Maupertuis 1756, II: 414.
} 
to promote attitudes of Western scientific superiority, Linnaeus himself was very conscious of the benefits of drawing on local systems of knowledge (as he himself did in Lapland) so that new forms of understanding could be produced from the mediation between the localised and the general.

Natural history focused particularly on indigenous knowledges of local products that might be useful to Europeans. When Cook set off on his Endeavour voyage, the president of the Royal Society, the earl of Morton, instructed him, for example, to observe of the people he encountered how they used plants: 'Their powers in Medicine, whether Salutary or noxious' and 'Particularly, such as give vivid or lasting colours for dyeing'. ${ }^{11}$ Banks took such injunctions seriously and made extensive enquiries on these points, especially among the Tahitians with whom he spent three months. He also took a close interest in their many medicinal herbs and admired their surgical techniques. Contact with the Australian Aborigines was much more limited, but Banks evidently sought out their names for local flora since he noted that 'they had a knowledge of plants as we plainly could perceive by their having names for them' ${ }^{12}$ Other European explorers also ventured into this 'contact zone' between cultures which made sharing of knowledge possible. While in Tahiti, Bougainville's naturalist, Philibert Commerson, immersed himself in ethnobotany, remarking that 'all their plants are known and distinguished with names that even indicate their affinities'.$^{13}$

The European quest for knowledge of and from the Pacific depended, however, on the cooperation of those on the other side of the beach to share information with the explorers and others who came in their wake. The willingness of indigenous peoples to give information about the world in which they lived differed with time and circumstance. In parts of Polynesia, lengthy sojourns by European visitors built up enough linguistic and cultural familiarity to provide at least some basis for communication. This generally led to a two-way exchange, the Polynesians being as curious about the Europeans as they were about them. Contacts with other societies such as the Australian Aborigines were, in the early stages, generally much more fleeting, though as Australia came under British rule contact inevitably became more extensive.

Establishing such 'contact zones' where Europeans and Indigenous peoples might exchange information required a good deal of mutual trust and understanding, which could take time to establish. On the Investigator voyage, Robert Brown seems to have been able to draw on some elements of Aboriginal knowledge of the local flora and fauna no doubt because he had two Aboriginal intermediaries,

11 Cook 1955-69, I: 517.

12 Banks 1962, I: 353, 375-376; II: 116.

13 Taillemite 1977, II: 507. 
Bungaree and Nanbaree, on board. It was very likely through their ability to establish rapport with the different Aboriginal groups encountered that Brown derived such knowledge as the native names for plants that he recorded in north Australia in 1803. ${ }^{14}$ A few days later, on 8 February, Peter Good, the gardener on board, wrote of the people of the Gulf of Carpentaria islands that '[i]t appears they have some knowledge of Botany and distinguish the different Trees \& vegetables by distinct names'. ${ }^{15}$ In Sydney, Brown appears to have built up a rapport with an Aboriginal by the name of Bagra since one of his notebooks includes 'Native names of Plants \& c. taken down from Bagra a very intelligent native of Broken Bay' along with lists of Aboriginal names for other plants and animals from elsewhere. ${ }^{16}$ Reliance on Aboriginal intermediaries was to continue. The naturalist, George Caley, who was dispatched to New South Wales by Joseph Banks, was, as he told Banks, dependent on an Aboriginal assistant who could 'trace anything so well in the woods'. One such collector, Moowattin, accompanied Caley back to London in 1810, spending a year there at the expense of Joseph Banks. ${ }^{17}$ When collecting botanical specimens from Western Australia in the early 1840s, Georgiana Molloy relied closely on an Aboriginal named Calgood. ${ }^{18}$ Given that the study of natural history extended to the human world, it is not surprising that some of Brown's natural history notebooks also include records of Aboriginal vocabularies. His 'New Holland plants notebook', for example, gives a list of some Aboriginal words for parts of the body as well as for plants. ${ }^{19}$

Knowledge of indigenous languages and customs could only come with protracted exposure to them and few had greater opportunities for such intensive immersion than the missionaries. Apart from the Spanish on the Marianas, these did not arrive in the South Seas until the last decade of the eighteenth century. The Protestant London Missionary Society missionaries were sent off to Tahiti with a formidable scientific agenda drawn up by the virtual founder of the society, Thomas Haweis (very likely at the behest of Joseph Banks). Special attention was to be paid to potential items of trade such as sandalwood or coconut oil. To obtain the latter effectively required the special skills the Tahitians had developed and so a report was requested on their 'art of breaking it [a coconut] with facility and dispatch' ${ }^{20}$

14 Vallance et al. 2001: 417.

15 Edwards 1981: 115.

16 Brown, papers, Natural History Museum, Vol. II, item 2, 44-51.

17 Clark 2008: 63, 66-67.

18 Lines 1994: 297, 301, 309.

19 Brown, papers, Vol. V, item 5, 61-3, 67; see also Brown, 'List ...', Natural History Museum.

20 Haweis et al., Collection of papers 1795-1802, Mitchell Library, MSS 4190X: Vol. 1, 18-20. 


\section{Cartography and navigation}

In their quest to map the largely unknown Pacific, Westerners were particularly eager to glean local geographical information even though localised forms of cartography often meshed awkwardly with Western conceptions of how to depict the world - something which was borne out in Captain Cook's lack of comprehension of the map of the Polynesian islands drawn up by the Tahitian navigator, Tupaia, on the Endeavour voyage. ${ }^{21}$ When, in 1596, Quirõs encountered the Santa Cruz archipelago (now a part of the Solomon Islands) he elicited from the indigenous people 'the names of all the islands, pointing out the bearings with their hands'. To get some sense of the distances, the Spanish also asked 'the number of days it took to go to each one'. Like most people, these informants expected some return for this knowledge, which, they hoped, would take the form of the Spanish using their firepower to attack their enemies whom they sought to blacken in Spanish eyes by describing as 'cannibals' ${ }^{22}$ With the aid of the two Vanuatuans whom he brought back with him to New Spain from his last voyage to the Pacific of 1605-06, Quirõs compiled a guide to some of the islands of Vanuatu and how to get to them. ${ }^{23}$

Early eighteenth-century Jesuit missionaries to the Micronesian Palau Islands recorded how the Paluans, using small stones, indicated the position of the different islands 'and marked out, as well as they could, the Name of each, its Extent and Distance from the others'. The Jesuits were so impressed with the resulting map that it was published in the Philosophical Transactions of the Royal Society in 1708-09. ${ }^{24}$ Soon afterwards another Jesuit missionary, Father Juan Cantova, drew on local reports to compile a map of the Micronesian Caroline Islands, which was accurate enough to be used by Otto von Kotzebue, navigator on the 1803-06 Russian circumnavigation of the earth under Ivan von Krusenstern. As part of his cartographical enquiries, Cantova also gained some information on Micronesian navigation techniques including the use of a 12-point compass. ${ }^{25}$

As the scale of European intrusion into the Pacific expanded there were more and more encounters with the seagoing techniques of the indigenous peoples of the Pacific, and particularly those of the Micronesians and Polynesians. Micronesian boat-building skills were greatly admired by European visitors. The French Lieutenant Crozet called in at Guam when returning from Marion

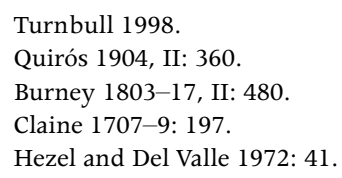


du Fresne's ill-fated voyage and thought that when it came to the construction of vessels 'they had nothing new to learn' ${ }^{26}$ Cook was similarly admiring of Polynesian boats.

Using such craft, as the European explorers came increasingly to appreciate, the Micronesian and Polynesian people, too, to a remarkable degree had overcome the 'tyranny of distance' dictated by the immensity of the Pacific. Navigational knowledge in Polynesian culture was sacred and the arts of the navigator were closely linked with those of the priest. Indeed, Tupaia, who accompanied Cook on his first voyage, combined both roles using his skills to bring Cook through the sea of islands surrounding Tahiti where Tupaia joined the Endeavour. As Banks wrote, what made Tupaia's presence on board 'more than anything else desirable is his experience in the navigation of these people and knowledge of the Islands in these seas; he has told us the names of above 70, the most of which he has himself been at. ${ }^{27}$ Other Tahitians, on occasions, also passed on their geographical knowledge to Europeans. When the Tahitian Pautu accompanied the Spanish Domingo de Bonechea on his 1772-73 voyage through the Tuamotu Archipelago, Pautu revealed that he had visited most of these islands. Having got to know the Spanish Tahitian-speaking Maximo Rodríguez well, Pautu later passed on details of Polynesian navigational techniques along with a list of some 42 islands. ${ }^{28}$ By the time that William Portlock arrived in the Micronesian Mariana Islands in 1788, the extent of contact with European vessels was such that he engaged a local indigenous pilot (who was chosen from a number of other possible contenders) to guide him to Macao. ${ }^{29}$ There Portlock sold the furs he had traded in the Pacific north-west.

Often, however, such hard-won navigational knowledge was treated with greater reticence. Another Tahitian on board one of Cook's ships, Mahine, who accompanied Cook for much of his second voyage before returning to Tahiti, told George Forster that few knew all the secrets of navigation - for these were sacred lore passed on only to an elite. A similar select knowledge economy prevailed in the Micronesian Marshall Islands. ${ }^{30}$ Indigenous navigational knowledge was the outcome of generations of close observation of the Pacific and its moods with the behaviour of all aspects of the environment, whether animate or inanimate, being minutely scrutinised for clues as to position and direction. Like European sailors, Polynesians looked to the stars as direction finders. After a three-month immersion in Tahitian society, Joseph Banks wrote of their observation of the stars that 'they know also the time of their annual appearing and disappearing

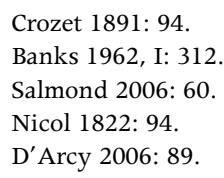


to a great nicety, far greater than would be easily believed by an European astronomer'. Their close study of the sky, thought Banks, was also apparent in their ability to predict the weather - a skill in which he found them 'far more clever than Europaeans'. ${ }^{31}$

As an aid to remembering the position of the stars, apprentice navigators in the Carolines were taught with maps of the sky made from objects such as coral, coconut leaves and banana fibres on mats. ${ }^{32}$ On board Cook's second voyage, George Forster encountered another such system of representation and memorisation when he noticed the way in which the Tahitian Mahine collected in New Zealand a number of small, slender twigs. These 'he carefully tied in a bundle, and made use of instead of journals'. Each island they visited was then represented by one of these twigs. The result, wrote Forster admiringly, was that 'he remembered the names perfectly well in the same order as we had seen them'. ${ }^{33}$ Another such device was the use of leaves to represent islands, something that Surgeon Anderson struck at Tonga. When he inquired the number of islands in that archipelago the Tongans 'reckon'd upwards of a hundred and fifty to us by bits of leaves' ${ }^{34}$

Such pictorial devices designed to preserve cartographical knowledge provided the bases for forms of maps. On occasions these were used in encounters between Europeans and the peoples of the Pacific to transmit knowledge across the cultural divide, providing what Michael Bravo calls a 'geographical gift' ${ }^{35}$ Such maps had been a part of cross-cultural contact since the days of Columbus. Indeed Columbus himself wrote that he had taken an Amerindian on board 'since the savage could draw a sort of chart of the coasts'. ${ }^{36}$ The most widely disseminated such Pacific geographical gift was the map of the Polynesian sea of islands (with the exclusion of the distant points of the Polynesian triangle at Hawai'i, New Zealand and Easter Island) drawn up by Tupaia while on the Endeavour - though the chart that was eventually printed was a redrawing by Cook and Johann Reinhold Forster. Polynesian seafaring traditions were also evident in the maps of New Zealand provided by Māoris. On Cook's Endeavour voyage, Māori chiefs drew up, at Cook's request, a map of much of the east coast of the north island of New Zealand by making a charcoal sketch on the deck of the ship. At Cook's bidding, too, they provided many place names. A still

31 Banks 1962, I: 368.

32 Lewis 2007, I: 367.

33 Forster 2000, I: 287.

34 Cook 1955-67, III: 957.

35 Bravo 1999.

36 De Vorsey 1978. 
more expansive map of the whole of New Zealand (excluding Stewart Island) was provided by the Māori Tuki in 1793 after he was kidnapped and taken to Norfolk Island to help establish a flax-growing industry there. ${ }^{37}$

Tuki's map (and possibly, too, the original one by Tupaia) was, in contrast to the map drawn in charcoal, put in a form that could be transported around the world. When La Pérouse arrived at the large island of Sakhalin in the Kuril chain off China, he encountered both transitory and more abiding forms of indigenous cartography. When questioned as to whether Sakhalin was an island or a peninsula, an elder drew a map showing that it was indeed an island while also sketching in the accompanying coastline of China with the strait in between. The map was drawn on the sand and met local needs, which were based on accumulated knowledge that did not require being recorded in more permanent forms. Interestingly, however, as La Pérouse wrote, another Sakhalin local seeing that the map was soon going to be washed away by the tide took 'one of our pencils with some paper; [and] he drew his island' ${ }^{38}$ Such familiarity with representations on paper may well have owed something to the proximity of the highly literate culture of China. As Bruno Latour has stressed, the transformation from a fugitive sketch on a tide-washed beach to an image that could be taken back to Paris to be reworked into maps of the globe brought with it the possibility of reconstructing the island of Sakhalin back at the Parisian 'centres of calculation'. The outcome of such a transformation in turn could provide the knowledge on which could be built global networks reaching from Paris to Sakhalin. ${ }^{39}$

\section{Conclusion}

As the human web expanded across the Pacific so, too, did the intersection of different forms of knowledge. Indigenous, locally based knowledge was drawn into Western-derived but increasingly universalising forms of classification, which could mask its origin. Central to the European scientific expeditions was the collecting impulse, which was given form and coherence through the pliable and plastic body of knowledge known as natural history with its systems of classification. Such systems were, however, well removed from the way in which indigenous people made sense of the world around them, employing classificatory categories which corresponded to their own needs and experience. For the people of the west coast of Vancouver Island, for example, the most basic divide in their taxonomy was between the animals of the sea and those of

37 Barton 1988.

38 Dunmore 1994-5, II: 290.

39 Latour 1987: 215-237. 
the land. ${ }^{40}$ Placing whales, sea otters and seals with land mammals as Western systems of classification did was, then, to translate their sense of the world into a quite different language. From a Western perspective, the increasingly scientific character of natural history had been linked with the passage away from medieval and early modern forms of an emblematic world view where plants and animals had potent symbolic significance. ${ }^{41}$ Yet for many indigenous societies, such as the Australian Aborigines, such talismanic understandings of the natural world were at the core of their cosmology. ${ }^{42}$

Natural history, with its reliance on a vast haul of specimens from all corners of the globe, was rooted in the local, but this was largely disguised by the forms in which it was conveyed and the systems used to give it order and intelligibility. As natural history evolved (an appropriate word) towards a more theoretically based and even more generalised history of nature with its culmination in theories of biological evolution, the focus was less and less on the particular and more on the general. The individual and local characteristics of a specimen were of less interest than the extent to which it fitted into a larger pattern that could extend well beyond the immediate locality. This growing global context of knowledge was made possible by the systems of recording, classification and storage that both promoted and were a response to the scientific voyaging to the Pacific and other parts of the globe.

Transmuting vast and confusing mounds of specimens into abstractions that could be manipulated in manageable ways provided a route to the growing level of generalisation characteristic of science. The most obvious form of abstraction was the recording of a new plant or animal by transfixing it with the neatness of a Latin binomial classificatory definition. The ingrained habit of recording information was reinforced forcibly by the habits of commerce and, as navigation grew more sophisticated, the discipline of shipboard life with its figure-filled journals. Much of this knowledge had come from indigenous sources, and the participation of investigators on both sides of the frontier in a common pursuit had engendered some fellow-feeling and a sense of a shared recognition of common goals. ${ }^{43}$ Nonetheless, the knowledge that was taken back to the Western repositories was transmuted into new and often unfamiliar forms.

Convergence between different peoples in the Pacific brought with it, then, a strong tendency to merge the local in the general. This was linked to the generalising impulse of Western science and its assumption that, wherever one was in the world, there could be only one truth - even if it was subject to

40 Moan 1978: 74-76.

41 Ashworth 1990.

42 Sutton 1988.

43 Cook 2012: 132. 
constant revision. The Christian missionaries also believed that there was one truth though, in practice, the symbolic language of religion and its variant ritual practices did lend itself to some forms of cultural pluralism. Science, however, was not so readily rendered plural though its view of the world and methods were, at least in theory, open to all. The science that was shaped by exploration of the globe and the convergence between peoples became itself a human web that both disguised and transcended its local origins. 'Once forged out of global experiences', writes Jacob, 'after the mid eighteenth century European knowledge systems became global. ${ }^{\prime 4}$

Science provided a world language that gradually spread beyond its European origins. Though still retaining strong links with the European thought-world out of which it had developed, it has proved accessible by humanity as whole. ${ }^{45}$ Potent though it was, it was and is but one form of knowledge and one particular way of understanding the world. Contact with indigenous cultures was and is a reminder that there are other systems of knowledge in which the symbolic and affinities between the human and the natural world provide other ways of understanding the place of human beings in a complex and still bewildering universe.

\section{References}

Ashworth, William B. 1990, 'Natural history and the emblematic world view', in Reappraisals of the Scientific Revolution, David C. Lindberg and Robert S. Westman (eds), Cambridge University Press, Cambridge, 303-332.

Banks, Joseph 1962, The Endeavour journal of Joseph Banks 1768-1771, J.C. Beaglehole (ed.), Public Library of New South Wales, Sydney, 2 vols.

Barton, Phillip 1988, 'Maori cartography and the European encounter', in Cartography in the Traditional African, American, Arctic, Australian, and Pacific Societies, David Woodward and G. Malcolm Lewis (eds), Vol. 2, Book 3 of History of Cartography, J.B. Harley and David Woodward (eds), University of Chicago Press, Chicago, 493-536.

Bravo, Michael 1999, 'Ethnographic navigation and the geographical gift', in Enlightenment and geography, D. Livingstone and C. Withers (eds), University of Chicago Press, Chicago, 199-235.

44 Jacob 2008: 342.

45 Pyenson 1990: 77-78. 
Brown, Robert, 'List of Aboriginal words, North Australia', Robert Brown papers, Misc. MSS, Box 2, Botany Library, Natural History Museum, London (microfilm, A[ustralian] J[oint] C[opying] Project M2495).

_ papers, Misc. MSS, New Holland Plants (2 boxes), Botany Library, Natural History Museum (typescript transcript of Aboriginal natural history vocabulary, Mitchell Library, Ab 88/2).

Burney, James 1803-17, A chronological history of the discoveries in the South Sea or Pacific Ocean, Luke Hansard \& Sons, London, 5 vols.

Chaplin, Joyce 2001, Subject Matter: Technology, the Body, and Science on the AngloAmerican Frontier, 1500-1676, Harvard University Press Cambridge, MA.

Claine, Paul 1707-9, 'An extract of two letters from the missionary Jesuits, concerning the discovery of the new Philippine-Islands, with a map of the same', Philosophical Transactions of the Royal Society 26: 189-199.

Clark, Philip 2008, Aboriginal Plant Collectors: Botanists and Australian Aboriginal People in the Nineteenth Century, Rosenburg Publishing, Sydney.

Cook, Harold J. 2004, 'Global economies and local knowledge in the East Indies: Jacobus Bontius learns the facts of nature', in Colonial Botany: Science, Commerce, and Politics, Londa Schiebinger and Claudia Swan (eds), University of Pennsylvania Press, Philadelphia, 100-118.

2007, Matters of Exchange: Commerce, Medicine, and Science in the Dutch Golden Age, Yale University Press, New Haven.

-2012, 'Moving about and finding things out: economies and science in the period of the Scientific Revolution', Osiris 27: 101-132.

Cook, James 1955-69, The journals of Captain James Cook on his voyages of Discovery, J.C. Beaglehole (ed.), Hakluyt Society, Cambridge, 3 vols in 4.

Crozet, Julien Marie 1891, Crozet's voyage to Tasmania, New Zealand and the Ladrone Islands and the Philippines in the years 1771-2, H. Ling Roth (trans.), Truslove and Shirley, London.

D'Arcy, Paul 2006, People of the Sea: Environment, Identity and History, University of Hawai'i Press, Honolulu.

De Vorsey, Louis 1978, Amerindian contributions to the mapping of North America: a preliminary view', Imago Mundi 30: 71-78. 
Drayton, Richard 2001, 'Knowledge and empire', The Oxford History of the British Empire, Wm. Roger Louis (ed.), vol. 2, The Eighteenth Century, P.J. Marshall (ed.), Oxford University Press, Oxford, 231-252.

Dunmore, John (ed.) 1994-5, The journal of Jean-François de Galaup de la Pérouse, 1785-1788, Hakluyt Society, London, 2 vols.

Edwards, Phyllis I. 1981, The Journal of Peter Good: Gardener on Matthew Flinders Voyage to Terra Australis 1801-03, British Museum (Natural History), London.

Forster, George 2000, A Voyage round the World, Nicholas Thomas and Oliver Berghof (eds) assisted by Jennifer Newell, University of Hawai'i Press, Honolulu, 2 vols.

Gascoigne, John 1996, 'The ordering of nature and the ordering of empire: a commentary', Visions of Empire: Voyages, Botany and Representations of Nature, David Philip Miller and Peter Hanns Reill (eds), Cambridge University Press, Cambridge, 107-113.

2014, Encountering the Pacific in the Age of the Enlightenment, Cambridge University Press, Cambridge.

Hallam, Sylvia 1987, 'Changing landscapes and societies: 15000 to 6000 years ago', in Australians to 1788, D.J. Mulvaney and J. Peter White (eds), Fairfax, Syme \& Weldon, Sydney, 47-73.

Haweis, Rev. Thomas and others, Collection of papers relating to early missions to the South Seas, 1795-1802, Mitchell Library, State Library of New South Wales, MSS 4190X.

Hezel, Francis X. and Maria Teresa Del Valle 1972, 'Early European contact with the Western Carolines, 1525-1750', Journal of Pacific History 7(1): 26-44.

Jacob, M.C. 2008, 'Afterward', in Science and Empire in the Atlantic World, James Delbourgo and Nicholas Dew (eds), Routledge, New York, 333-344.

Latour, Bruno 1987, Science in Action: How to Follow Scientists and Engineers through Society, Harvard University Press, Cambridge, MA.

Lewis, G. Malcolm 2007, 'Cartography: an overview, indigenous cartography, and speculative cartography', in Oxford Encyclopedia of Maritime History, John B. Hattendorf (ed.), Oxford University Press, Oxford, 4 vols, I: 366-369.

Lines, William 1994, An all Consuming Passion: Origins, Modernity, and the Australian Life of Georgiana Molloy, Allen \& Unwin, Sydney. 
Maupertuis, Pierre 1756, Lettre sur le progès des sciences in his Oeuvres, Lyon, 4 vols, II: 375-431.

Moan, Barbara 1978, 'Vanished companions: the changing relationship of the West Coast People to the animal world', Sound Heritage 7(1): 71-7.

Nicol, John 1822, The Life and Adventures of John Nicol, Mariner, William Blackwood, Edinburgh.

Pratt, Mary Louise 1992, Imperial Eyes: Travel Writing and Transculturation, Routledge, London.

Pyenson, Lewis 1990, 'Why science may serve political ends: cultural imperialism and the mission to civilize', Berichte zur Wissenchaftesgeschichte 13: 69-81.

Quirós, Pedro Fernandez de 1904, The voyages of Pedro Fernandez de Quiros, 1590 to 1606, Sir Clements Markham (ed.), Hakluyt Society, London, 2 vols.

Raj, Kapil 2004, 'Surgeons, fakirs, merchants, and craftspeople: making l'empereur's jardin in early modern South Asia', in Colonial Botany: Science, Commerce, and Politics, Londa Schiebinger and Claudia Swan (eds), University of Pennsylvania Press, Philadelphia, 252-269.

Salmond, Anne 2006, 'Cross-cultural voyaging: the first Spanish visits to Tahiti, 1772-1776', Spain's Legacy in the Pacific, Mains'l Haul. A Journal of Pacific Maritime History 42: 54-65.

Smith, Pamela H. and Paula Findlen 2002, 'Commerce and the representation of nature in art and science', in Merchants and Marvels: Commerce, Science and Art in Early Modern Europe, Pamela H. Smith and Paula Findlen (eds), Routledge, New York, 1-25.

Sutton, Peter 1988, 'Icons of country: topographical representations in classical Aboriginal traditions', in Cartography in the Traditional African, American, Arctic, Australian, and Pacific Societies, David Woodward and G. Malcolm Lewis (eds), Vol. 2, Book 3 of History of Cartography, J.B. Harley and David Woodward (eds), University of Chicago Press, Chicago, 353-386.

Taillemite, Étienne (ed.) 1977, Bougainville et ses compagnons autour du monde 1766-9, Imprimerie nationale, Paris, 2 vols.

Turnbull, David 1998, 'Cook and Tupaia, a tale of cartographic méconnaissance', in Science and Exploration in the Pacific: European Voyages in the Southern Oceans in the Eighteenth Century, Margarette Lincoln (ed.), Boydell Press, Woodbridge, Suffolk, 117-132. 
7. CROSS-CULTURAL KNOWLEDGE EXCHANGE IN THE AGE OF THE ENLIGHTENMENT

Vallance, T.G., D.T. Moore and Eric W. Groves 2001, Nature's Investigator: The Diary of Robert Brown in Australia 1801-1805, Australian Biological Resources Study, Canberra. 
This text is taken from Indigenous Intermediaries: New Perspectives on Exploration Archives, edited by Shino Konishi, Maria Nugent and Tiffany Shellam, published 2015 by ANU Press, The Australian National University, Canberra, Australia. 